\title{
"Antecedents to consumer buying behavior: the case of consumers in a developing country"
}

$\begin{array}{ll} & \text { Eric E. Mang'unyi id https://orcid.org/0000-0002-5035-104X } \\ \text { AUTHORS } & \text { Krishna K. Govender iD https://orcid.org/0000-0002-3079-5989 } \\ & \text { R http://www.researcherid.com/rid/U-1710-2017 }\end{array}$

\begin{tabular}{|c|c|}
\hline ARTICLE INFO & $\begin{array}{l}\text { Eric E. Mang'unyi and Krishna K. Govender (2019). Antecedents to consumer } \\
\text { buying behavior: the case of consumers in a developing country. Innovative } \\
\text { Marketing , 15(3), 99-115. doi:10.21511/im.15(3).2019.08 }\end{array}$ \\
\hline DOI & http://dx.doi.org/10.21511/im.15(3).2019.08 \\
\hline RELEASED ON & Friday, 27 September 2019 \\
\hline RECEIVED ON & Wednesday, 31 July 2019 \\
\hline \multirow[t]{2}{*}{ ACCEPTED ON } & Friday, 13 September 2019 \\
\hline & $(\mathrm{cc}) \mathrm{EY}$ \\
\hline LICENSE & $\begin{array}{l}\text { This work is licensed under a Creative Commons Attribution } 4.0 \text { International } \\
\text { License }\end{array}$ \\
\hline JOURNAL & "Innovative Marketing " \\
\hline ISSN PRINT & $1814-2427$ \\
\hline ISSN ONLINE & $1816-6326$ \\
\hline PUBLISHER & LLC "Consulting Publishing Company "Business Perspectives" \\
\hline FOUNDER & LLC "Consulting Publishing Company "Business Perspectives" \\
\hline
\end{tabular}

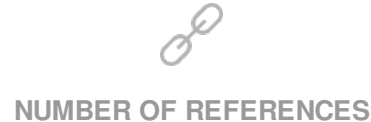

76

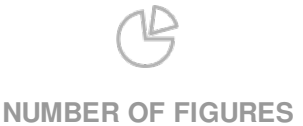

3
ニニ:-

NUMBER OF TABLES

7

(C) The author(s) 2022. This publication is an open access article. 


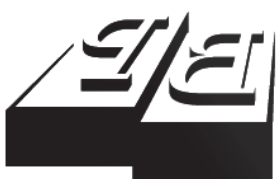

BUSINESS PERSPECTIVES

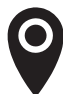

LLC "CPC "Business Perspectives" Hryhorii Skovoroda lane, 10, Sumy, 40022, Ukraine

www.businessperspectives.org

Received on: $31^{\text {st }}$ of July, 2019 Accepted on: $13^{\text {th }}$ of September, 2019

(c) Eric E. Mang'unyi, Krishna K. Govender, 2019

Eric E. Mang'unyi, Ph.D., Lecturer, School of Business, The Catholic University of Eastern Africa, Nairobi, Kenya.

Krishna K. Govender, Ph.D., Professor, School of Management, IT and Governance University of KwaZulu-Natal, Durban, South Africa.

\section{(ㄷ) (i)}

This is an Open Access article, distributed under the terms of the Creative Commons Attribution 4.0 International license, which permits unrestricted re-use, distribution, and reproduction in any medium, provided the original work is properly cited.

\section{ANTECEDENTS TO CONSUMER BUYING BEHAVIOR: THE CASE OF CONSUMERS IN A DEVELOPING COUNTRY}

\begin{abstract}
While consumers play a very crucial role in the marketing strategies of companies, effective development of strategies must satisfy their needs and wants. Therefore, an evaluation and understanding of the underlying factors and/or dimensions influencing consumer buying behavior are critical for supermarkets to both retain and acquire new customers. The article reports on factors impacting the consumer buying behavior and the relationship among the factors. The study uses data from a cross-sectional survey conducted within a random sample of 699 customers at 17 supermarkets in Nairobi, Kenya. Reliability and factorial validity of the self-administered questionnaire were evaluated and considered satisfactory, while structural equation modelling (SEM) was used to test several hypotheses. Social characteristics were a good predictor of the consumers' inclination to patronize a supermarket, thus directly influencing the buying behavior. A strong positive connection between psychological factors and buying behavior was ascertained based on income, which suggests that although psychological characteristics impact consumer attitudes towards the supermarket, income and education levels may well play a determining role in this regard. Retail marketers in general and in Kenya in particular are encouraged to be cognizant of the above when developing strategic marketing programs to increase the level of patronage. As a research paper, the study is limited to the data and prior empirical research. It offers the benefit of new research directions for marketing managers in understanding and satisfying the consumers. The main contribution of the present research, interdisciplinary in nature due to combining elements linked to both marketing and psychology, is its focus on consumer buying behavior towards supermarkets in a developing country, thus producing revealing insights.
\end{abstract}

\section{Keywords buying behavior, behavior patterns, customers, supermarket, Kenya, patronage}

\section{JEL Classification $\quad$ M31}

\section{INTRODUCTION}

Considering the economic challenges faced by consumers, especially those in developing countries, it has become essential for consumers to 'shop' for their daily needs (Sanlier \& Karakus, 2010; Yap, Tong, \& Lai, 2011; Yang, Do, Wang, Chang, \& Hung, 2011). However, consumers the world over are also becoming more educated, sophisticated and discerning, and in addition to price, they also consider factors such as the service experience, location, ambience, aesthetic, architectural leisure when making decisions to purchase from a particular store (Diallo, 2015; Hinson, Anning-Dorson, \& Kastner, 2012; Ouma, Mwangi, \& Oduk, 2013; Pandey, Khare, \& Bhardwaj, 2015). Other reasons include limited time (Heider \& Moeller, 2012; Zairis \& Evangelos, 2014), proximity and/or easy access (Pandey et al., 2015), quality of products and services, and shopping hours (Zairis \& Evangelos, 2014), bulk purchasing benefits (Han, Ye, Fu, \& Chen, 2014) and an opportunity for people to interact and socialize (Pandey et al., 2015). Therefore, focusing on 'total' consumer needs is critical for competing effectively and overall business performance (Furaiji, Łatuszyńska, \& Wawrzyniak, 2012; Gunay \& Baker, 2011). 
Consumers' changing behaviors are used to inform marketing strategies (Yap et al., 2011; Diallo, Chandon, Cliquet, \& Philippe, 2013). Thus, to be effective in the development of plans, consumers' needs must be fulfilled (Goodhope, 2013). An evaluation and understanding of the underlying factors and/or dimensions influencing consumer buying behavior is critical for supermarkets to both retain and acquire new customers.

Although there are claims that consumer behavior is complex to describe, numerous definitions exist, but all converge on the consumer as a human being. For example, Mohan, Sivakumaran, and Sharma (2013) relate consumer behavior with individual personality traits and situational (economic) determinants. Priest, Carter, and Stat (2013) refer to consumer behavior as the rational, passionate and physical activities undertaken by consumers when making a decision to acquire, use, and dispose products and services that meet their needs and wants. Consumer behavior is also defined as the need to consume, search and evaluate the information, choose a product and experience its outcomes (satisfaction/dissatisfaction) (Nguyen, de Leeuw, \& Dullaert, 2016, p. 2). Since consumer behavior revolves around three roles (user, payer, purchaser) played by the customer (Furaiji et al., 2012), and in line with the aforementioned definitions, we refer to consumer behavior as the whole consideration processes, stimuli, actions undertaken by consumers in buying and using a product or a service including those who connect them (Goodhope, 2013; Hoyer, Maclnnis, \& Pieters, 2013; Nguyen, de Leeuw, \& Dullaert, 2016).

In the marketing literature, among the numerous antecedents identified to correlate with consumer behavior, four distinct dimensions emerge, namely psychological, economic, social and cultural (Diallo et al., 2013; Durmaz, 2014; Furaiji et al., 2012; Kurajdova \& Taborecka-Petrovicova, 2015; Mohan et al., 2013; Sethi \& Chawla, 2014). Economic factors were identified such as household income, product price and quality, psychological factors include store perceptions/image, general environment (Hoppe, Vieira, \& de Barcellos, 2013), and previous experiences (Agnoli, Capitello, \& Begalli, 2016), while socio-cultural include encouragements from family members, education and social class (Akpan, 2016; Callwood, 2013; Diallo, 2012; Pantano, 2011). In addition, there is a growing stream of recent research into variables perceived to have an impact on consumer behavior in the developing economies. For example, Erdil (2015) and $\mathrm{Wu}$, Yeh, and Hsiao (2011) examined the connection of store attributes like intention to purchase, brand and price images on buying behavior, while Mohan et al. (2013) postulated that store environment positively spurred impulse buying behavior among consumers. Diallo (2015) argued that price and store image, value and consumer attitude strongly sway behavior towards a store brand. Pandey et al. (2015) focused on the impact of three factors, namely culture, price and cosmopolitanism, on loyalty towards local store.

Several researchers (Cao \& Pederzoli, 2013; Diallo, 2015; Ouma et al., 2013; Pandey et al., 2015) argue for more rigorous empirical testing of consumer behavior research in the emerging countries. In light of the above, this paper reports on the efforts to investigate further and deeper the ways in which several factors impact consumer buying behavior and more so, the ways in which the relationships differ across demographic categories. Furthermore, Kenya is an emerging market and, as such, consumers cannot be grouped as homogenous, hence it may be important to understand the consumer behavior. Understanding consumer buying behavior is essential for the development of effective marketing strategies and programs for the supermarket chain in Kenya. Consumers in Kenya prefer shopping in 'large' supermarkets (Ouma et al., 2013; Wambugu, 2015), and they buy various products at affordable prices, find entertainment, comfortable atmosphere, facilities for eating and parking (Zairis \& Evangelos, 2014). Supermarket chains, both foreign-based and locally-based, have increased tremendously in Kenya and reached 28 in 2017, and the trend seems to continue, since there is potential in the country's retail sector (Ouma et al., 2013).

The study quantitatively explored consumers' perceptions towards supermarkets with the aim of isolating the influencing attributes of buying behavior. This supplies unique learning to marketing strate- 
gists and scholars alike in their marketing programs by highlighting the critical dimensions towards consumer behavior in a developing country and also compares to extant literature. Furthermore, the paper's unique contribution is that it takes an interdisciplinary perspective by combining the elements linked to both marketing and psychology. Thus, the result-based analysis can be considered as a basis to locate areas pertinent to consumer behavior where improvements are needed, or areas where resources may be utilized more efficiently valuable to marketers in the retail sector. The rest of the paper is structured as follows. The theoretical and conceptual framework, research model and literature review, followed by materials and methods implemented, analysis and results are presented. The results are discussed and the study is concluded in the last section.

\section{THEORETICAL AND CONCEPTUAL FRAMEWORK, RESEARCH MODEL AND LITERATURE REVIEW}

Although the literature on consumer behavior is growing daily, there is still much more to learn about how consumer behavior connects with the purchasing decision making process, particularly with regard to supermarket patronage in an emerging competitive African economy (Ouma et al., 2013). This section examines the factors that affect the consumer buying behavior (Kotler \& Armstrong, 2012).

\subsection{Cultural aspects}

Recent research has shown the importance of cultural characteristics inherent in an individual or group of people, which inspires product or service consumption decisions. These factors relate to shared norms and traditions or customs of a given society (Furaiji et al., 2012; Miao, Jalees, Qabool, \& Zaman, 2019), which are learned through socialization over time. Therefore, the attitudes and norms of an individual or social group play a critical role in influencing the consumer behavior (Leeraphong \& Mardjo, 2013; Jen \& Wang, 2015; Wang, Liu, \& Qi, 2014). A mixed methods study by Pantano (2011) and empirical research by Cakanlar and Nguyen (2019), and Dörtyol, Coşkun, and Kitapci (2018) demonstrated that culture-related factors had a positive and significant correlation with consumers' perceptions and their subsequent behavior towards local products. Akpan's (2016) study in Nigeria found that cultural factors significantly correlated with consumer buying behavior, while Pandey et al. (2015) posited that cultural factors strongly correlated with consumer loyalty and behavior towards a retailer. Callwood (2013) and Mehta, Sharma, and Swami (2013) posit that individual beliefs, attitudes, learning and motivations determine consumption behaviors towards a product or a service.

\subsection{Economic aspects}

Economic factors, which are also referred to by some researchers (Mohan et al., 2013; Mullis \& Kim, 2011) as situational, correlate with consumer buying behavior. Specifically, the factors revolve around monetary aspects, such as income and the price of a product or service. Clarke and Banga (2010), Han et al. (2014), and Roy (2012) have posited that price is a major determinant in supermarket patronage and loyalty. Price is the amount paid for the purchase of a product or a service (Dörtyol et al., 2018; Furaiji et al., 2012). An obvious perception among buyers of products or services from retailers has always been determined by the costs that would be incurred. Some researchers (Ahmed, 2012; Oke, Kamolshotiros, Popoola, Ajagbe, \& Olujobi, 2016) have argued that while concerns of price and quality among other product or service-related aspects are the main drivers of buying decisions in the developed countries, the case may not always apply to consumers in the developing countries. In the food industry, Shashikiran and Madhavaiah (2015) revealed a strong and positive correlation between economic factors and the consumers buying behavior of food products. Similarly, Joshi and Rahman (2015), Wingrove and Urban (2017) found that price and product quality sway an individual's decision to indulge in or believe in certain products.

Another characteristic associated with an individual's economic situation is income, which is the 
monetary value received by a person from an organization for the work done (Vadim, n.d.). The aforementioned researcher found that income level correlates with consumer behavior. However, it has also been suggested that increased income pushes consumers to prefer brand names rather than price level per se (Gunay \& Baker, 2011). Consumers with a higher propensity to spend are more likely to shop often and in some cases without plan (impulsively) (Han et al., 2014; Mohan et al., 2013). On the contrary, those with lower incomes or the poor may exhibit different buying behavior, like, for example, being more price conscious (Kumar, Dangi, \& Vohra, 2015; Miao et al., 2019), when deciding on patronizing a supermarket (Ibok \& Umana, 2013).

\subsection{Psychological aspects}

According to Kotler and Armstrong (2012), an individual's behavior is determined by motivation, learning, perception and attitudes. Mohan et al. (2013) relate consumer behavior with individual personality traits, status and class, time of the day or week, environment and/or store location. Therefore, a consumer is able to assess a product or service and make an informed decision to purchase, based on previous interaction with a product.

While exploring the motivators of consumer behavior in an online platform, Cetină, Munthiu, and Rădulecu (2012) categorized mainly psychological (perception, trust, personality, website aesthetics), and social factors (reference groups, social status and family) to determine the consumer behavior. Durmaz (2014) found that psychological factors have an impact on the consumer behavior.

\subsection{Social aspects}

Joshi and Rahman (2015) assert that social factors determine the consumer behavior in the green shopping context. Social factors include reference groups, family size and composition, social value of the product, friends or social group and its leader. The effect comes from acts, feelings, attitudes, considerations of a person through relations with other people or groups. Other peoples' love towards each other and acknowledgement of its existence among them affects their consumer behavior (Durmaz, 2014).
According to Mohan et al. (2013), high sales in the supermarket result from shoppers who come in groups and to some extent these members may lead to impulse buying. Therefore, targeting social groups has been used by many supermarkets as a marketing strategy to increase the sales. The social identity within the groups may drive consumers to ask themselves what kind of product or service fulfills their preferences. Reference group has been found to have a significantly positive effect on consumer buying behavior (He, Cai, Deng, \& Li, 2016). In the virtual space, Cetină et al. (2012) identify virtual groups as the key determinants of consumers' choices and behavior. Social team leaders contribute to the buying behavior of their group members (Kwon \& Song, 2015), while in the food industry social factors have also been found to impact on the buying behavior (Shashikiran \& Madhavaiah, 2015). The family size and composition (Sanlier \& Karakus, 2010) affect the family consumer behavior, either on a member individual basis or collectively as a family. Companions, for example, children, spouse, friends, affect the purchase decisions and subsequently the product items bought (Eze \& Ndubisi, 2013; Joshi \& Rahman, 2015; Salazar, Oerlemans, \& van StroeBiezen, 2013; Tsarenko, Ferraro, Sands, \& McLeod, 2013). Perceived quality and the social value of a product (Kakkos, Trivellas, \& Sdrolias, 2015) has been associated with the consumer buying behavior. Family, cultural environment and economic reality are directly linked to consumer behavior (Hoppe et al., 2013).

\subsection{Demographics}

Some researchers (Hinson et al., 2012; Olsen \& Skallerud, 2011; Zairis \& Evangelos, 2014) have posited that demographics, namely, age, gender, status, education and income level, significantly correlate with consumer behavior. For example, it is argued that at different stages of life, consumer needs, wants and preferences change. The reasons that would drive young consumers to purchase products are different from those that would drive older people. Cetină et al. (2012) suggest that an increase in income would also increase purchase frequency among males and females, and they conclude that there is a significant difference between males and females. Males may consider less information and take a short route to making 
the decisions, which impacts purchase frequency, market segmentation strategies and store choices (Liu, Brock, Cheng, Rongwei, \& Tseng, 2013; Olsen \& Skallerud, 2011).

A highly educated person is likely to possess adequate knowledge and understanding about a product and store, thus being in a better position to make a purchase decision (Yap et al., 2011). Gunay and Baker (2011) assert that an educated consumer is more conscious of preferred products or services, and thus conclude that consumer demographic characteristics correlate with their behavior towards a product and their preferences.

\subsection{Conceptual framework, objectives and hypotheses}

Based on the hypothesized relationships, a conceptual model (Figure 1) derived from a thorough review of literature to include four dimensions as antecedents of consumer behavior was proposed. The literature, for example, Callwood (2013), Diallo et al. (2013), Durmaz (2014), Furaiji et al. (2012), Pantano (2011), Sethi and Chawla (2014), Shashikiran and Madhavaiah (2015), has shown that in the retail market, customers perceived psychological, personal, economic and socio-cultural, among other related factors, important determinants of consumer behavior. The aforementioned factors fall within the aegis of human behavior model/s, the underlying support for this study. According to Kotler (1965), knowing the real reasons why people buy is a daunting task, as they are subject to numerous influences. As stated by Runyon and Stewart (1987), this theory postulates the beliefs held about human beings and the causes of their behavior. As such, human beings can therefore be viewed from many viewpoints. For example, from an economic viewpoint, sellers may use economic incentives to influence the consumers, while from a socio-cultural viewpoint, consumers are influenced via associations, appeals to group norms, references and values. Nevertheless, a criticism to this model/s of human behavior is that it is incomplete in describing human beings, since diverse theories may be suitable to not the same marketing situations (Runyon \& Stewart, 1987). On the whole, human behavior theory(ies) are pertinent to consumer behavior, since they enable to gain an accurate and deep understanding of human beings and, as such, an effort to explain their purchase decisions.

In this study, therefore, the psychological factors include consumer perception about the supermarket, general environment, i.e. ambience, décor, layout, music and packaging, previous experiences, needs and advertisements. Economic factors were monthly income, product pricing, quality of products and availability of product variety. With regard to socio-cultural factors, we looked at the aspects such as the ways in which family members and companions sway the behavior, social status, availability of products for all age groups, education status, home geographical location and family traditions.

The conceptual model demonstrates the direct effect of the psychological, economic, social and cultural factors/dimensions on consumer buying behavior. In this regard, it can be stated that the literature on the subject could likely benefit from testing the existing theories in a developing country such as Kenya. A deductive, exploratory approach is applied in order to test the hypotheses and the conceptual model.

Supermarkets have been a subject for various studies concerning retailer-consumer interactions and this paper contributes to better understanding the determinants of consumer behavior by focusing on four objectives, namely:

- to identify the important factors that impact consumer preference for a specific supermarket chain;

- to explore the relationship between the economic, social, cultural and psychological dimensions of consumer behavior;

- to ascertain the differences in buying behavior between the high- and low-income consumers;

- to determine the differences in buying behavior between higher- and lower-educated consumers.

In relation to the literature review and the abovementioned research objectives, and with respect to Kenyan consumers, it is posited that cultural, eco- 


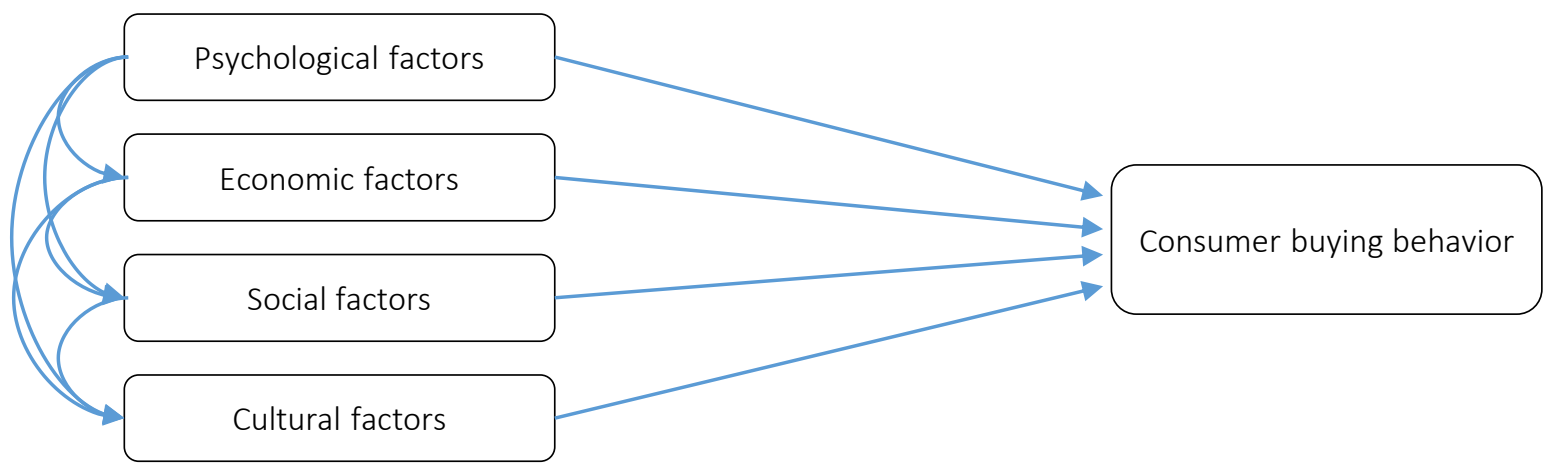

Figure 1. Conceptual framework

nomic, psychological and social elements motivate their choice of a particular supermarket and result in continued patronage of this supermarket. Hence, in order to empirically establish whether the aforementioned is true, it is hypothesized as follows:

H1: There is a positive and significant relationship between the cultural dimensions (education, home geographical region, family tradition) of Kenyan consumers and consumer behavior.

H2: There is a positive and significant relationship between the economic dimensions (monthly income, product price, quality and variety) and consumer behavior.

H3: There is a positive and significant relationship between the psychological dimensions (perceptions, environment, previous experiences, needs and advertisements) and consumer behavior.

H4: There is a positive and significant relationship between the Kenyan consumers' social dimensions (family members and friends, companions, social status, available products for all age categories) and their consumer behavior.

Further, the following hypotheses were formulated to explore the relationships with regard to education and income, more especially in the context of Kenyan consumers.

H5: There is no significant difference in the Kenyan consumers' buying behavior be- tween the lower- and higher-educated consumer groups.

H6: There is no significant difference in the Kenyan consumers' buying behavior between the low-income and high-income consumer groups.

\section{MATERIALS AND METHODS}

\subsection{Research design}

The study adopted a quantitative approach using a survey design. The hypothetico-deductive approach to research theory application was used in order to define the concepts, test hypotheses, advance the theory and predict the interrelationships, and thus assist in generalization (Creswell, 2014; Pietersen \& Maree, 2015). By utilizing the positivism philosophy, emphasis was placed on objectivity in the methods and the entire study, enabling the identification of key elements to be measured (Lincoln, Lynham, \& Guba, 2011).

\subsection{Sample determination and sampling procedures}

The selection of the retail chain supermarkets was based on three criteria, namely the leader in the Kenyan retail market, it targets all consumer segments, although mostly perceived to medium-to-high income levels, and it sells quality products. Convenience sampling of the supermarket chain customers allowed for consumer 
heterogeneity and ensured sample randomness (Saunders, Lewis, Thornhill, \& Guppa, 2007).

Since this was a quantitative survey targeted at all customers who were shopping and/or believed to regularly shop in that particular supermarket chain in the Kenya's state capital (Nairobi), participant selection was based on systematic random sampling procedure, using the 'consumer/shopper intercept' method, whereby one in every five customers ( $k$-th respondent) exiting the store was approached to participate in the survey.

Since in probability sampling, the larger the sample size, the lower the level of precision in the generalization of the results to the entire population (Creswell, 2014), a large sample was essential for this study. In consumer marketing surveys, a minimum of 300 cases is favored (Diallo, 2015; Mohan et al., 2013; Pandey et al., 2015), and in addition, Kline (2011) argues that to determine the adequate effects of SEM, the sample size needs to be in excess of 200 cases. Puszczak, Fronczyk, and Urbański's (2013) sample formula was used to calculate most suitable sample size at $95 \%$ confidence level, assuming a normal distribution:

$$
n=\frac{N}{1+N \cdot(e)^{2}},
$$

where $n$ - sample size, $N$ - population size and $e$ - probability of error.

In particular, the above formula made it possible to maintain an error of 5\% for the sample survey (Berenson, Levine, \& Krehbiel, 2012).

\subsection{Data collection}

A survey was conducted over the course of two weeks by visiting the supermarket outlets in March 2016. Respondents were surveyed at different times of the day and week, which helped reduce sampling errors and bias. To ensure that participants had adequate information to form an opinion about their buying behavior, participants were provided with adequate information about the study. Three research assistants were recruited and trained to collect the data. The training included instructions on how to engage the participants and convince them to participate in the survey and how to collect the data. Participants were asked to complete the consent forms before participating in the survey. Generally, the questionnaire took 1020 minutes to complete, and the data were collected until the self-saturation point of 750 was reached. However, during the data cleaning, 51 of the questionnaires were omitted due to either missing data or improper responses, which resulted in responses from 699 usable questionnaires being analyzed.

\subsection{Measures}

Measures of the research dimensions were drawn from a comprehensive review of the literature and modified for the purposes of this study. The scales of Furaiji et al. (2012), Goodhope (2013), Durmaz (2014) were adapted for this study. After development, the instrument was tested among 20 customers, and their comments were used to revise some items in order to improve clarity and understandability. All items were measured on a five-point Likert scale ranging from strongly disagree (1) to strongly agree (5). A total of 17 structured questions were formulated, which were subsequently broken down into the following four dimensions: psychological and economic (5) items each, social (4) and cultural (3), which form the basis of the findings. The content and face validity of each item were assessed by two experts who were familiar with the research topic. In summary, the questionnaire was structured as follows: the first section covered the socio-demographic items, the second section included scaled items on the dimensions, and the third section consisted of categorical data that measured consumer behavior.

\subsection{Data analysis}

Data were analyzed using SPSS 21 and AMOS 24 software packages for Windows. The first step was the Exploratory Factor Analysis (EFA) to summarize the multiple factorial measures of the constructs to a smaller number of factors (Field, 2009). The SEM technique was used to predict the causal relationships among several latent variables (Kline, 2011; Niemelä-Nyrhinen \& Leskinen, 2014), enabling clarity and testability of competing models, and to test the effects 
(direct, indirect or both), and the 'fit' of various integrated linear models. In addition, the measurement model (construct validity) was scrutinized with Confirmatory Factor Analysis (CFA), which evaluates how well latent variables are measured by observed variables (Chen, Zhang, Liu, \& Mo, 2011, p. 243), before testing the structure paths (Lee, Ooi, Tan, \& Chong, 2010).

\subsection{Research ethics}

An important aspect during data collection pertains to confidentiality of participants, informed consent and voluntary participation (Leedy \& Omrod, 2010, pp. 101-104). All individuals that were approached to participate in the survey were assured that confidentiality will be strictly maintained, and the respondents were not required to provide their names or any other identification in the questionnaires. The participants were also informed that participation in the study was voluntary; and no one was coerced to participate. The questionnaire was accompanied by a consent letter, which requested the agreement to participate in the study. In addition, all questionnaires were stored in a lockable room, while processed information was secured in a password protected computer and external hard drive.

\section{ANALYSIS AND RESULTS}

\subsection{Reliability}

To evaluate the reliability of the research variables, it was necessary to determine Cronbach's alpha ( $\alpha$ ) coefficients of the scale measurements as suggested by Creswell $(2015$, p. 215). The internal consistency of all the variables indicated that all items had a value of slightly more than 0.5 (Table 1 ), which are still considered acceptable (Pantano, 2011).

Table 1. Scale reliability

\begin{tabular}{l|c|c}
\hline $\begin{array}{c}\text { Variables } \\
\text { correlation }\end{array}$ & $\boldsymbol{\alpha}$ coefficients & No. of items \\
\hline Psychological & 0.644 & 5 \\
\hline Cultural & 0.543 & 3 \\
\hline Economical & 0.505 & 5 \\
\hline Social & 0.548 & 4 \\
\hline
\end{tabular}

\subsection{Validity}

Spearman's rank correlation (rho) for each construct and highly correlated variables in each construct were grouped together by computing their average. Highly correlated variables carry the same information, hence this principle used to reduce the number of variables. Thereafter, the issues of dimensionality and validity (construct and discriminant) were handled using Principle Component Analysis (PCA) to identify the different groupings of variables of interest (Creswell, 2015). From the rotated factor loadings (Table 2), five factors were generated, which were greater than 0.5 , implying that they had internal consistency, thus making them high enough for further analysis (Hair et al., 2010).

Table 2. Rotated factor loading matrix

\begin{tabular}{|c|c|c|c|c|c|}
\hline Variables & $\begin{array}{c}\text { Factor } \\
1\end{array}$ & $\begin{array}{c}\text { Factor } \\
2\end{array}$ & $\begin{array}{c}\text { Factor } \\
3\end{array}$ & $\begin{array}{c}\text { Factor } \\
4\end{array}$ & $\begin{array}{c}\text { Factor } \\
5\end{array}$ \\
\hline Psychology_1 & .045 & -.063 & -.027 & .756 & -.166 \\
\hline Psychology_2 & .005 & .053 & -.067 & .694 & -.066 \\
\hline Psychology_3 & -.051 & .052 & .145 & .642 & .111 \\
\hline Psychology_4 & -.011 & .029 & -.039 & .625 & .243 \\
\hline Economic_2 & .011 & .928 & -.067 & .083 & -.007 \\
\hline Economic_3 & -.003 & .619 & .124 & -.070 & .024 \\
\hline Economic_4 & .029 & .922 & -.140 & .081 & -.019 \\
\hline Social_1 & .916 & .012 & -.023 & -.027 & .001 \\
\hline Social_2 & .907 & .020 & -.030 & -.022 & -.020 \\
\hline Social_3 & .916 & -.030 & -.027 & -.008 & .027 \\
\hline Social_4 & .885 & .028 & .091 & .050 & .018 \\
\hline Culture_1 & -.006 & .127 & -.037 & -.130 & .706 \\
\hline Culture_2 & -.039 & .093 & .017 & .098 & .642 \\
\hline Culture_3 & .060 & -.151 & -.013 & .041 & .769 \\
\hline Behavior_1 & -.016 & .037 & .853 & -.051 & .059 \\
\hline Behavior_2 & .011 & -.016 & .950 & .031 & -.028 \\
\hline Behavior_3 & .003 & -.008 & .935 & .017 & .004 \\
\hline
\end{tabular}

Further, the descriptive statistics of factors and their indicators are presented in Table 3. These factors and/or items were developed following the previous research in this area (for example, Kotler \& Armstrong, 2012), as exemplified in the literature review section. 
Table 3. Descriptive statistics of factors and their measurement

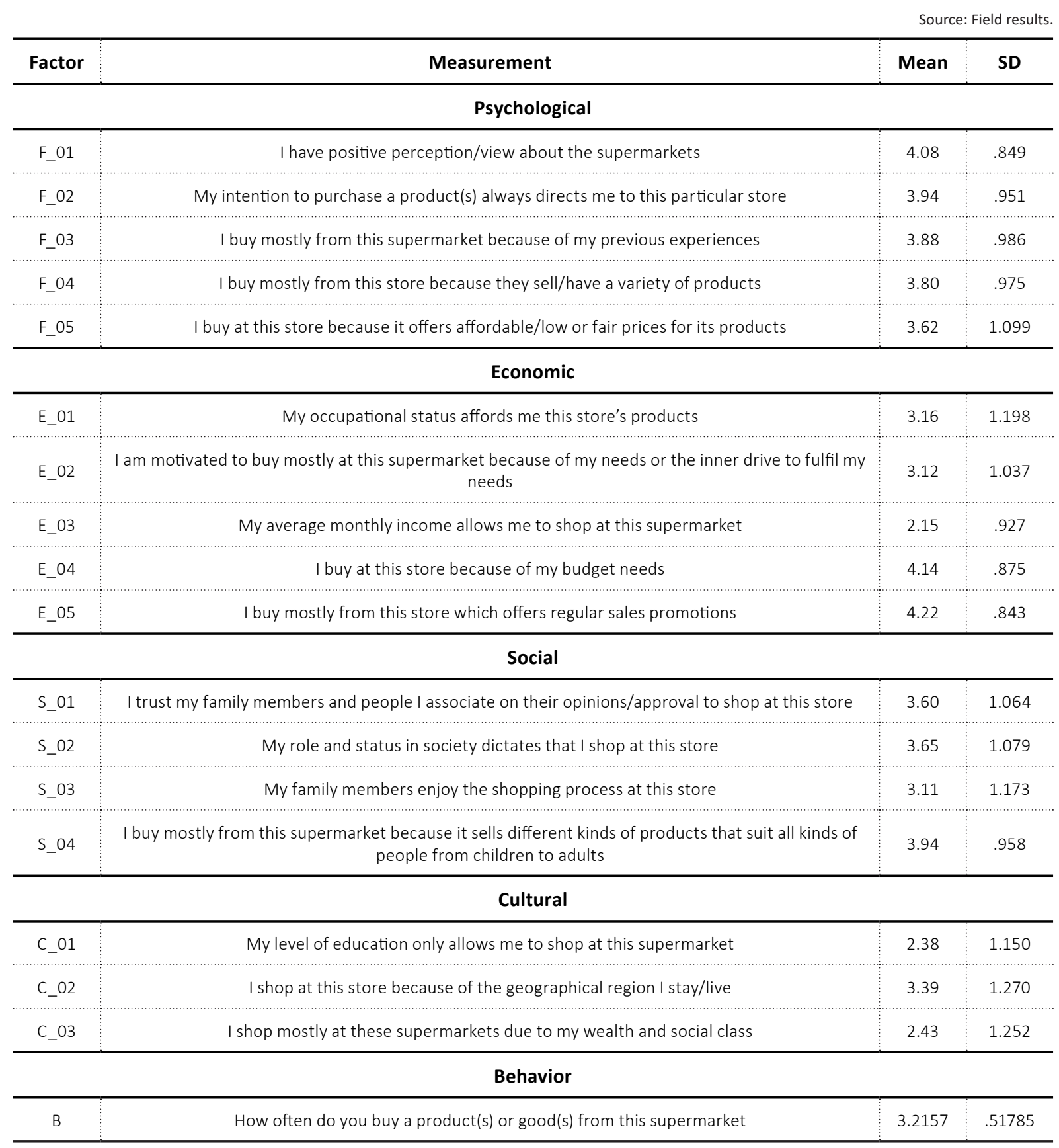

\subsection{Empirical testing of the hypothesized model}

Based on the Analysis of Moments Structure (AMOS) software, the model was found to be adequate with minimum requirements of goodnessof-fit indices achieved. The fit of the model to the data was checked using Goodness-of-Fit Index (GFI), Adjusted Goodness-of-Fit Index (AGFI), Root Mean Square Error of Approximation (RMSEA), Root-Mean-Square Residual Index
(RMR) and the ratio of Chi square value to degrees of freedom (CMIN/DF). Small RMSEA values, particularly less than 0.04 , indicate that the model fits the data well, and CMIN/DF values less than 3 show a better fit (Schumacker \& Lomax, 2015). In this study, $\mathrm{CMIN}=32.026$, $\mathrm{df}=18, p>0.05, \mathrm{CMIN} / \mathrm{DF}=1.779, \mathrm{RMR}=.013$, GFI $=.993$, AGFI $=.965$ and $\mathrm{RMSEA}=0.033$, all of which indicate that the model fitted the data reasonably well. The structural model is illustrated in Figure 2. 


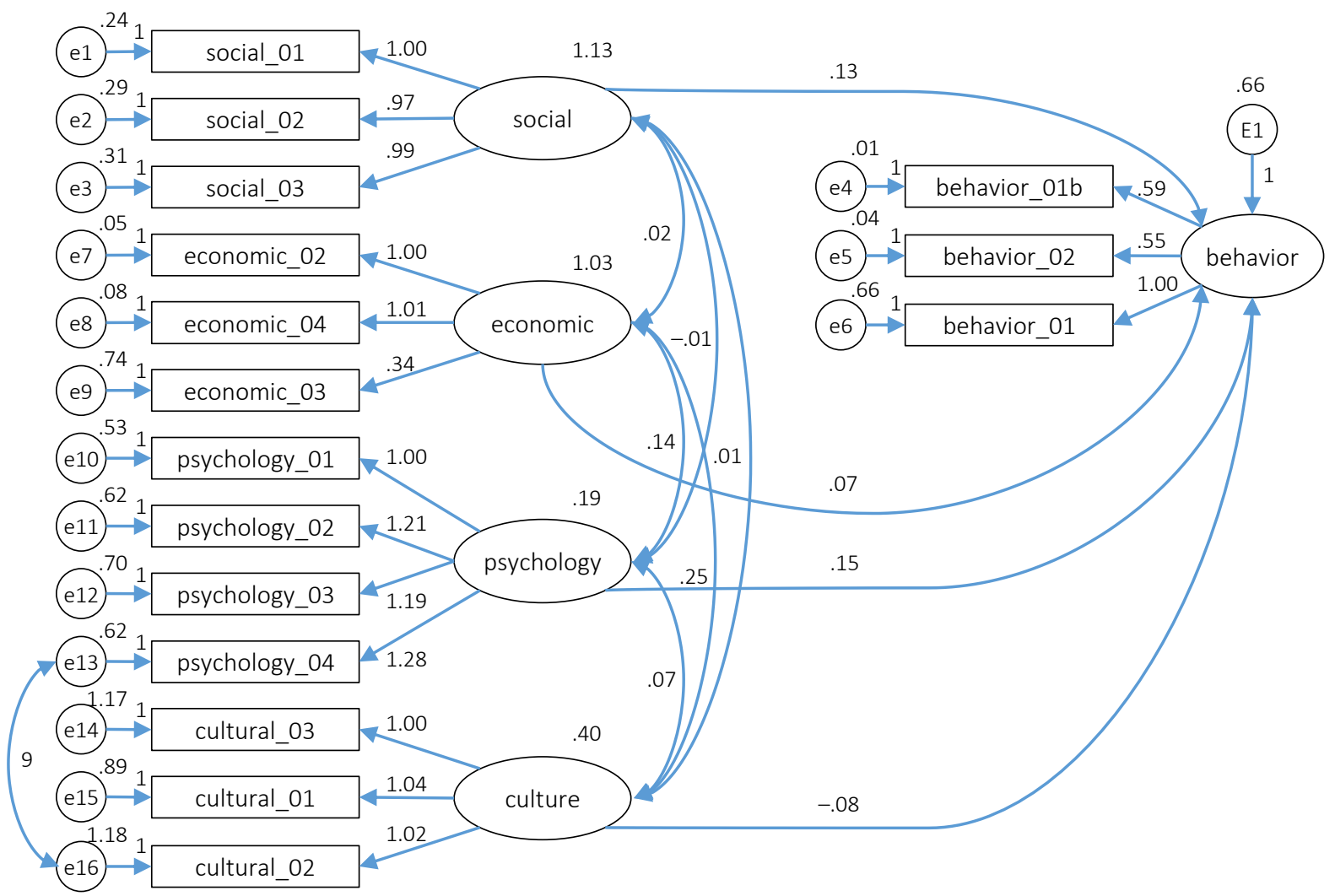

Figure 2. Structural model

\subsection{Hypothesized relationships}

Structural equation modelling was performed to test the hypotheses and the outcome is reflected in Table 4.

While the critical ratio (CR) less than 1.96 $(p>0.0001)$ would imply a non-significant relationship (Arbuckler, 2012), it is evident in Table 4 that most of the factors were significant at 0.05 level, because their $\mathrm{CR}$ values were more than 1.96 (Hair et al., 2010; Kline, 2011). Based on the results, hypothesis $\mathrm{H} 4$ was supported, implying that social factors positively and significantly determined the consumer buying behavior $(\beta=0.134, p<0.05)$. Hypotheses $H 1, H 2$, and $H 3$ were not supported. However, it is also important to note that although hypothesis $\mathrm{H3}$ was not significant, it exhibited a weak positive relationship with consumer buying behavior, while cultural factors showed a negative relationship with consumer behavior.

Table 4. Model parameter maximum likelihood estimates

\begin{tabular}{|c|c|c|c|c|c|c|c|}
\hline \multicolumn{3}{|c|}{ Hypothesized relationship } & \multirow{2}{*}{ Path coefficient } & \multirow{2}{*}{ S.E. } & \multirow{2}{*}{$t$-value } & \multirow{2}{*}{$p$-value } & \multirow{2}{*}{ Outcome } \\
\hline Latent variable & & Measured variables & & & & & \\
\hline Behavior & $\leftarrow$ & Social & .134 & .031 & 4.293 & $* * *$ & $\mathrm{~S}$ \\
\hline Behavior & $\leftarrow$ & Economic & .069 & .038 & 1.801 & .072 & NS \\
\hline Behavior & $\leftarrow$ & Psychology & .153 & .099 & 1.536 & .125 & NS \\
\hline Behavior & $\leftarrow$ & Culture & -.076 & .079 & -.971 & .332 & NS \\
\hline Social_01 & $\leftarrow$ & Social & 1.000 & - & - & - & - \\
\hline Social_02 & $\leftarrow$ & Social & .972 & .029 & 33.745 & $* * *$ & - \\
\hline Social_03 & $\leftarrow$ & Social & .992 & .030 & 33.603 & $* * *$ & - \\
\hline Behavior 01 & $\leftarrow$ & Behavior & .592 & .024 & 24.725 & $* * *$ & - \\
\hline Behavior 02 & $\leftarrow$ & Behavior & .553 & .023 & 24.586 & $* * *$ & - \\
\hline Behavior 03 & $\leftarrow$ & Behavior & 1.000 & - & - & - & - \\
\hline
\end{tabular}


Table 4 (cont.). Model parameter maximum likelihood estimates

\begin{tabular}{|c|c|c|c|c|c|c|c|}
\hline \multicolumn{3}{|c|}{ Hypothesized relationship } & \multirow{2}{*}{ Path coefficient } & \multirow{2}{*}{ S.E. } & \multirow{2}{*}{$t$-value } & \multirow{2}{*}{$p$-value } & \multirow{2}{*}{ Outcome } \\
\hline Latent variable & & Measured variables & & & & & \\
\hline Economic_02 & $\leftarrow$ & Economic & 1.000 & - & - & - & - \\
\hline Economic_04 & $\leftarrow$ & Economic & 1.011 & .028 & 36.608 & $* * *$ & - \\
\hline Economic_03 & $\leftarrow$ & Economic & .339 & .033 & 10.235 & $* * *$ & - \\
\hline Psychology_01 & $\leftarrow$ & Psychology & 1.000 & - & - & - & - \\
\hline Psychology_02 & $\leftarrow$ & Psychology & 1.210 & .142 & 8.531 & $* * *$ & - \\
\hline Psychology_03 & $\leftarrow$ & Psychology & 1.192 & .143 & 8.355 & $* * *$ & - \\
\hline psychology_04 & $\leftarrow$ & Psychology & 1.279 & .148 & 8.664 & $* * *$ & - \\
\hline Culture_03 & $\leftarrow$ & Culture & 1.000 & - & - & - & - \\
\hline Culture_01 & $\leftarrow$ & Culture & 1.044 & .148 & 7.031 & $* * *$ & - \\
\hline Culture_02 & $\leftarrow$ & Culture & 1.018 & .145 & 7.004 & $* * *$ & - \\
\hline
\end{tabular}

Notes: ${ }^{* * *}$ Coefficient significant at the 0.0001 level, $\mathrm{S}$ - supported, NS - not supported.

\subsection{Differences among groups}

As can be seen from Table 5, the more educated consumers are, the greater their buying behavior is determined by psychological factors (Beta $=.830$ ), social factors $($ Beta $=0.360)$ and cultural factors $($ Beta $=-1.060)$. The results also show that there was no significant difference between lower- and higher-educated groups of customers. Considering the above findings, hypothesis $\mathrm{H} 5$ is accepted.

The results in Table 6 show that the sample mean has a $z$-score $\geq$ to the critical value of 1.645 , which is significant at the 0.05 level. Thus, with regard to income-based consumer categories, the most influential factor the for buying behavior is the psy- chological factor (Beta $=.740$ and $.870, p<0.05)$, since it showed a strong positive and significant effect on consumer behavior. The previously described findings imply a significant relationship, therefore rejection of hypothesis H6. However, considering individually other factors, certain similarities among income categories can be outlined. Thus, economic (lower: Beta $=.460$, higher: Beta $=0.420$ ) and social (lower: Beta $=.310$; higher: beta $=0.370$ ) factors positively determine the consumer behavior, while cultural aspects (Beta $=-1.090$ and -1.020$)$ for low- and high-income categories, respectively, had a negative relationship with consumer behavior. Economic, social and cultural factors did not affect significantly the consumer buying behavior.

Table 5. Education

\begin{tabular}{|c|c|c|c|c|c|c|c|}
\hline \multirow{2}{*}{ Path to } & & \multirow{2}{*}{ Path from } & \multicolumn{2}{|c|}{ Low } & \multicolumn{2}{|c|}{ High } & \multirow{2}{*}{ z-score } \\
\hline & & & Estimate & $P$ & Estimate & $P$ & \\
\hline Behavior & $\leftarrow$ & Psychological & 0.720 & 0.000 & 0.830 & 0.000 & 1.480 \\
\hline Behavior & $\leftarrow$ & Economic & 0.490 & 0.000 & 0.420 & 0.000 & -0.610 \\
\hline Behavior & $\leftarrow$ & Social & 0.300 & 0.000 & 0.360 & 0.000 & 0.650 \\
\hline Behavior & $\leftarrow$ & Cultural & -0.940 & 0.000 & -1.060 & 0.000 & -0.660 \\
\hline Behavior & $\leftarrow$ & Gender & 0.060 & 0.290 & 0.020 & 0.430 & -0.630 \\
\hline Behavior & $\leftarrow$ & Age bracket & -0.030 & 0.410 & 0.010 & 0.450 & 1.060 \\
\hline
\end{tabular}

Notes: $* * * p$-value $<0.01, * * p$-value $<0.05, * p$-value $<0.10$.

Table 6. Income

\begin{tabular}{|c|c|c|c|c|c|c|c|}
\hline \multirow{2}{*}{ Path to } & & \multirow{2}{*}{ Path from } & \multicolumn{2}{|c|}{ Lower } & \multicolumn{2}{|c|}{ Higher } & \multirow{2}{*}{ z-score } \\
\hline & & & Estimate & $P$ & Estimate & $P$ & \\
\hline Behavior & $\leftarrow$ & Psychological & 0.740 & 0.000 & 0.870 & 0.000 & $2.32 * *$ \\
\hline Behavior & $\leftarrow$ & Economic & 0.460 & 0.000 & 0.420 & 0.000 & -0.420 \\
\hline Behavior & $\leftarrow$ & Social & 0.310 & 0.000 & 0.370 & 0.000 & 0.750 \\
\hline Behavior & $\leftarrow$ & Cultural & -1.090 & 0.000 & -1.020 & 0.000 & 0.470 \\
\hline Behavior & $\leftarrow$ & Gender & 0.010 & 0.750 & 0.050 & 0.070 & 0.770 \\
\hline Behavior & $\leftarrow$ & Age bracket & 0.020 & 0.550 & 0.010 & 0.700 & -0.310 \\
\hline
\end{tabular}

Notes: $* * * p$-value $<0.01, * * p$-value $<0.05, * p$-value $<0.10$. 


\subsection{Relationship among the variables}

To facilitate further interpretation, the interaction effect between the predictor variables was plotted and the simple slopes related to each interaction effect among the variables were calculated. As shown in Figure 3A, economy dampens the positive relationship between the psychological aspects and consumer behavior towards purchasing of goods at the supermarket. Similarly, Figure 3C shows that psychology dampens the positive relationship between culture and the consumer behavior towards purchases of goods at the supermarket. The aforementioned results imply that if the economic environment is weak, for instance, then it will psychologically impact the buyers and their buying behavior. Figures 3B and 3D illustrate that cultural aspects strengthen the positive relationship between the economy and consumer behavior, while culture strengthens the positive relationship between the social aspects and consumer behavior, respectively. For example, an edu-

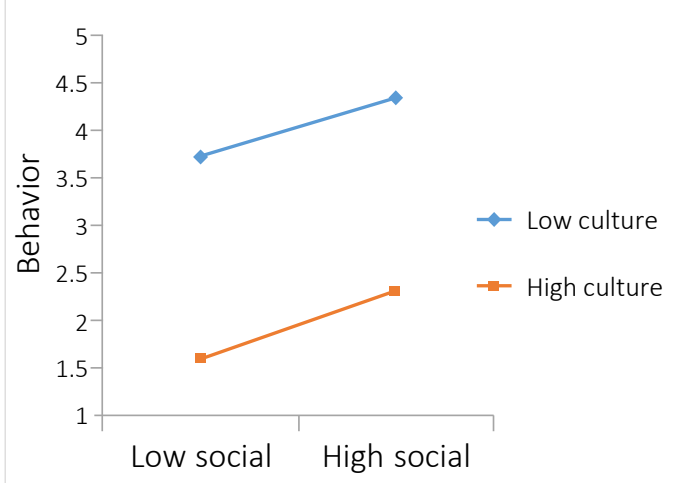

Psychological

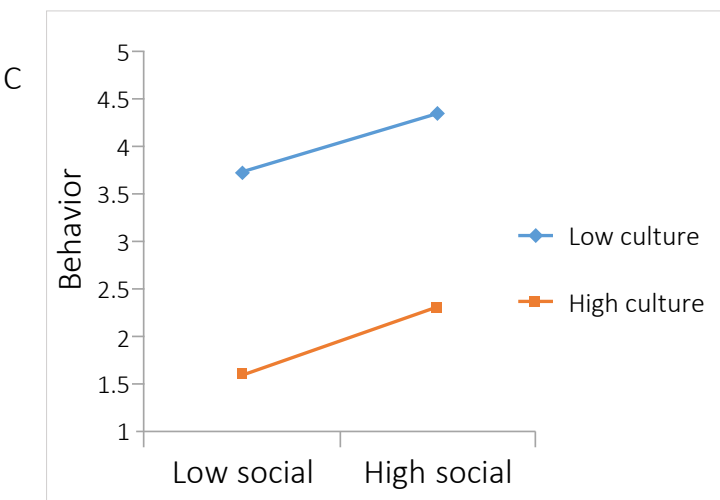

Cultural cated person means a higher social status than an uneducated individual, which means economically empowered, therefore, is swayed by traditions that have been practiced by the family towards shopping in a particular supermarket.

\subsection{Summary of the research results}

Table 7. Results of hypotheses testing

\begin{tabular}{l|c:c}
\hline Hypotheses & $\begin{array}{c}\text { Levels of } \\
\text { significance }\end{array}$ & $\begin{array}{c}\text { Outcome } \\
\text { (accepted/ } \\
\text { rejected) }\end{array}$ \\
\hline H1: Cultural dimensions $\rightarrow$ CB & .332 & Rejected \\
\hdashline H2: Economic dimensions $\rightarrow$ CB & .072 & Rejected \\
\hline H3: Psychological dimensions $\rightarrow$ CB & .125 & Rejected \\
\hline H4: Social dimensions $\rightarrow$ CB & $* * *$ & Accepted \\
\hdashline H5: Education (low/high) $\rightarrow$ CB & $* * *$ & Accepted \\
\hdashline H6: Income (low/high) $\rightarrow$ CB & $p>0.05$ & Rejected \\
\hline
\end{tabular}

Notes: CB represents consumer behavior, $* * *$ represents significance at 0.01 level, ** represents significance at 0.05 level.

From Table 7, it is clear that social dimensions to consumer behavior (CB) and education level/s

Source: Authors' own research.

B

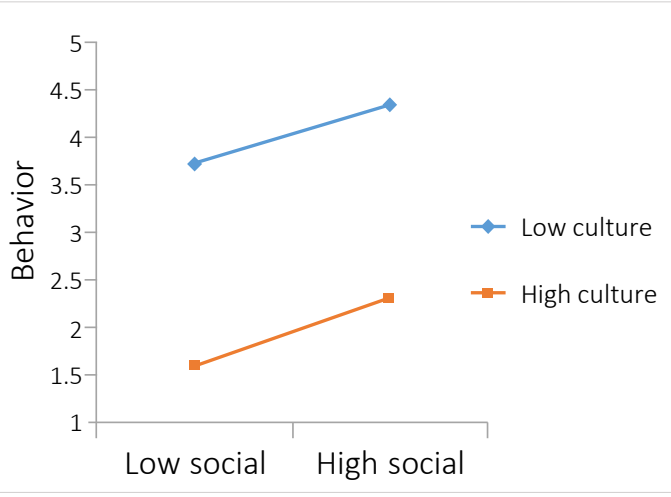

Economical

D

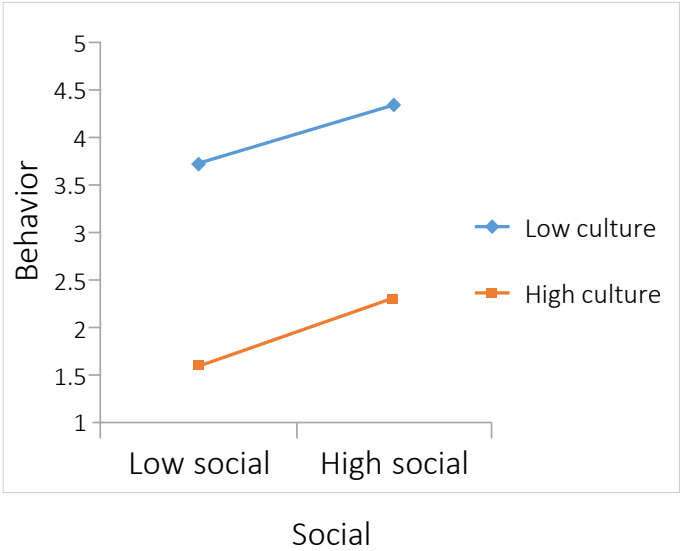

Figure 3. Relationship between the predictor variables 
to consumer behavior (CB) are significant at 0.01 level $\left({ }^{* *}\right)$. The aforementioned hypotheses were therefore accepted. On the contrary, cultural dimensions to $\mathrm{CB}$, economic dimensions to $\mathrm{CB}$ and psychological dimensions to $\mathrm{CB}$ are not significant having a higher $p$-value. With regard to income levels (high/low) among consumer groups, no differences existed, hence $\mathrm{H} 6$ was rejected, because $p>0.05$.

In respect to the main body of the research model, only one (H4) out of four research hypotheses was supported. The aforementioned results have proved that social dimensions among Kenyan consumers determined their buying behavior. Further, the results also indicate that education levels of consumers do not significantly influence their buying behavior.

\section{DISCUSSION}

The behavior of customers at the supermarket chain stores is mostly determined by social factors and not by economic, cultural and psychological factors. Customers were more swayed by opinions and/or approval from family members and other close associates, their social status and the variety of products being sold at the supermarket in their choice of a supermarket. The relationship between social factors and consumer behavior was moderate but highly significant. The high effect of social factors on consumer buying behavior was in line with other research (Cetină et al., 2012; He et al., 2016; Joshi \& Rahman, 2015; Kakkos et al., 2015).

On the other hand, the positive relationship between the psychological factors and consumer behavior, and also between the economic factors and consumer behavior was reasonable, though the insignificant paths are supported by Ahmed (2012), Dörtyol et al. (2018), Han et al. (2014), Kotler and Armstrong (2012), implying that the customer actual buying behavior at the supermarket tends to be driven by other factors as well. Unlike the previous research, the negative relationship between cultural factors and consumer behavior was not significant (Pandey et al., 2015). The aforementioned insignificant results are surprising, since economic, psychological and cultural factors are key and have been shown both to impact and favor consumer buying behavior. A focus on consumers' cultural value attached to products is one strategy that can be applied by marketers. Furthermore, such customized strategies can help penetrate some culturally segmented markets.

The effect of the relationship between psychological aspects and buying behavior is reduced by the state of the economy, which impacts on a customer's willingness to purchase at the supermarket. On the same vein, psychology makes the relationship between the culture and the consumer behavior less strong. Therefore, a weak economic environment psychologically could impact the buyers and their buying behavior. Culture has a positive effect on the relationship between social aspects (Miao et al., 2019), economy and consumer behavior.

With regard to group differences, the results showed that irrespective of the education level, consumer behavior is not significantly determined by education. It means that the supermarket does not necessarily have to segment its market in terms of levels of education. Consumers choose to shop at a specific supermarket mainly to cover their daily needs and save time on shopping. On the other hand, in relation to income-based consumer categories, the psychological characteristics had a strong positive and significant effect on consumer behavior. The findings imply that in order to obtain the increased consumer patronage, which is related to behavior, marketing actions and communications by the supermarket chain should be tailored according to specific expected reactions of each income-based segment of the market.

The sample chosen was limited to one supermarket chain in the capital city of Kenya, thus future studies may expand the sample to let go this weakness, and also aim at repeating the study using alternate methods that will enable single out more detailed factors, which affect the consumer behavior. Possible mediating factors such as customer trust, quality competitive positioning, and consumer satisfaction, etc. were not considered. Integrating them into a structural equations model, with factors measured in this study as exogenous and consumer behavior as endogenous variable need to be investigated. Demographic factors can also be investigated and a modification to the scales is also suggested. 


\section{CONCLUSION}

Even though focusing on one supermarket chain might seem a constricted approach, both the analyzed sub-sector and the investigated region remain of high importance for studying the consumer behavior. In the context of this study, it is concluded that social and psychological factors exert great control on consumer buying behavior and, as such, patronage of the supermarket. However, in the current competitive industry, supermarkets should consider all four variables to increase the market share.

Characteristically, most consumers in the developing countries tend to be less individualistic than in Western societies (Gbadamosi, 2016). They care more about others and like to be identified as part of it, hence this is similar to consumers in the Kenyan context, as the study results have suggested that social factors have a great impact on the buying behavior.

As mentioned earlier in this paper, the studied retail chain supermarket has been associated with selling the quality products. Recently, Kenya has experienced a growing middle-class of which literature has suggested that such consumers tend to have varied needs, hence trade-off between what they can afford, brand and quality. This may have implication as to why they are showing greater levels of brand loyalty for the supermarket. An inclination towards a brand indicates that these segments of consumers are more risk-averse, which could be a result of inadequate information about the existing alternatives as opposed to consumers in the developed countries.

The current study found that regardless of the education level, psychological characteristics significantly correlated with the buying behavior. Education has been found to be a determinant of buying behavior in the developed world, also drive buying behavior among customers in a developing country such as Kenya. Education level assists the consumer with the knowledge with regard to advantages and disadvantages of spending or saving. Also, income levels help in making a decision about costs or saving, although it was not found to have a significant influence among different income groups of consumers.

Since income and education levels have a great impact on consumer buying behavior in choice of supermarkets, marketing activities should be geared towards segmenting markets adequately in order to serve different target markets profitably. However, it should be done with caution. To cater for all markets, super premium and normal products should be stocked, since stocking and/or selling products or services for one market segment only could lead the supermarket losing some of its customers depending on which market they decide to serve (i.e. premium or normal) for they would have been left out.

The conclusion drawn from the study is that some frameworks developed and applied in other countries for studying the consumer buyer behavior are applicable for studying the consumer behavior in the developing countries. This research postulates a modest solution that would assist in shaping strategies in advertisements and marketing to cover not only the entire Kenyan market, but also other emerging markets in Africa and beyond for profitability purposes for retail chain supermarkets.

\section{REFERENCES}

1. Agnoli, L., Capitello, R., \& Begalli, D. (2016). Behind Intention and Behavior: Factors Influencing Wine Consumption in A Novice Market. British Food Journal, 118(3), 660-678. https:// doi.org/10.1108/BFJ-05-20150181
2. Ahmed, E. K. (2012). Consumer Behavior Differences between Developed and Developing Countries. Retrieved from https://www.sambuno.com/ consumer-behavior-differencesdeveloped-developing-countries/ (accessed on April 15, 2017).
3. Akpan, S. J. (2016). The Influence of Cultural Factors on Consumer Buying Behavior towards Pork. British Journal of Marketing Studies, 4(6), 44-57.

4. Arbuckler, J. (2012). IBM, SPSS, AMOS 21 User's Guide. AMOS Development Corporation. 
Retrieved from https://www. pdfdrive.com/ibm-spss-amos24-users-guide-e34473898.html

5. Berenson, M., Levine, D., \& Krehbiel, T. (2012). Basic Business Statistics: Concepts and Applications (12th ed.). England: Pearson Education Limited.

6. Cakanlar, A., \& Nguyen, T. (2019). The influence of culture on impulse buying. Journal of Consumer Marketing, 36(1), 12-23. http://dx.doi.org/10.1108/JCM03-2017-2139

7. Callwood, K. (2013). Psychological Factors That Influence Consumer Buying Behavior. Retrieved from http://www.ehow.com/ list_7599973_psychological-influence-consumer-buying-behavior. html (accessed on April 14, 2017).

8. Cao, L., \& Pederzoli, D. (2013). International Retailers' Strategic Responses to Institutional Environment of Emerging Market: Multiple Case Studies in China. International Journal of Retail and Distribution Management, 41(4), 289-310. https://doi. org/10.1108/09590551311330555

9. Cetină, I., Munthiu, M. C., \& Rădulecu, V. (2012). Psychological and Social Factors that Influence Online Consumer Behavior. Procedia - Social and Behavioral Sciences, 62, 184-188. https://doi. org/10.1016/j.sbspro.2012.09.029

10. Chen, Y., Zhang, Y., Liu, J., \& Mo, P. (2011). Interrelationships among Critical Success Factors of Construction Projects Based on Structural Equation Model. Journal of Management in Engineering, 28, 243-251. Retrieved from https://ascelibrary. org/doi/abs/10.1061/\%28ASCE\%2 9ME.1943-5479.0000104

11. Clarke, I., \& Banga, S. (2010). The Economic and Social Role of Small Stores: A Review of UK Evidence. The International Review of Retail, Distribution and Consumer Research, 20(2), 187-215. https://doi. org/10.1080/09593961003701783

12. Creswell, J. W. (2014). Research Design: Qualitative, Quantitative and Mixed Methods Approaches.
Thousand Oaks, CA: Sage Publications, Inc. Retrieved from https://www.amazon.com/ Research-Design-QualitativeQuantitative-Approaches/ $\mathrm{dp} / 1452226105$

13. Creswell, J. W. (2015). Research Methods (4th ed.). Lincoln: Sage Publications.

14. Diallo, M. F. (2012). Effects of Store Image and Store Brand Price-Image on Store Brand Purchase Intention: Application to an Emerging Market. Journal of Retailing \& Consumer Services, 19(3), 360-367. https:// doi.org/10.1016/j.jretconser.2012.03.010

15. Diallo, M. F. (2015). Drivers of Store Brands Usage in an Asian Emerging Market: Evidence Vietnam. International Journal of Retail \& Distribution Management, 43(12), 1144-1161. http://dx.doi. org/10.1108/IJRDM-07-2014-0086

16. Diallo, M. F., Chandon, J. L., Cliquet, G., \& Philippe, J. (2013). Factors Influencing Consumer Behavior Towards Store Brands: Evidence from the French Market. International Journal of Retail \& Distribution Management, 41(6), 422-441. https://doi. org/10.1108/09590551311330816

17. Dörtyol, I. T., Coşkun, A., \& Kitapci, O. (2018). A Review of Factors Affecting Turkish Consumer Behavior. In Marketing Management in Turkey (Marketing in Emerging Markets) (pp. 105139). Emerald Publishing Limited. https://doi.org/10.1108/978-178714-557-320181010

18. Durmaz, Y. (2014). The Impact of Psychological Factors on Consumer Buying Behavior and an Empirical Application in Turkey. Asian Social Science, 10(6), 194-204. https://doi.org/10.5539/ ass.v10n6p194

19. Erdil, T. S. (2015). Effects of Customer Brand Perceptions on Store Image and Purchase Intention: An Application in Apparel Clothing. Procedia Social and Behavioral Sciences, 207, 196-205. https://doi.org/10.1016/j. sbspro.2015.10.088
20. Eze, U. C., \& Ndubisi, N. O. (2013). Green Buyer Behavior: Evidence from Asia Consumers. Journal of Asian and African Studies, 48(4), 413-426. https://doi.org /10.1177\%2F0021909613493602

21. Furaiji, F., Łatuszyńska, M., \& Wawrzyniak, A. (2012). An Empirical Study of the Factors Influencing Consumer Behavior in the Electric Appliances Market. Contemporary Economics, 6(3), 76-86. https://doi.org/10.5709/ ce.1897-9254.52

22. Gbadamosi, A. (2016). Consumer Behavior in Developing Nations: A Conceptual Overview. Retrieved from http://www.igi-global.com

23. Goodhope, O. O. (2013). Major Classic Consumer Buying Behavior Models: Implications for Marketing Decision-Making. Journal of Economics and Sustainable Development, 4(4), 164-172. Retrieved from https:// www.iiste.org/Journals/index.php/ JEDS/article/view/4844

24. Gunay, G. N., \& Baker, M. J. (2011). The Factors Influencing Consumers' Behavior on Wine Consumption in The Turkish Wine Market. EuroMed Journal of Business, 6(3), 324-341. http://dx.doi. org/10.1108/14502191111170150

25. Hair, J. F., Black, W. C., Babin, B. J., \& Anderson, R. E. (2010). Multivariate Data Analysis: A Global Perspective. New York: Pearson Prentice Hall.

26. Han, S., Ye, Y., Fu, X., \& Chen, Z. (2014). Category Role Aided Market Segmentation Approach to Convenience Store Chain Category Management. Decision Support Systems, 57, 296-308. http://dx.doi.org/10.1016/j. dss.2013.09.017

27. He, A., Cai, T., Deng, T., \& Li, X. (2016). Factors Affecting Non-Green Consumer Behavior: An Exploratory Study Among Chinese Consumers. International Journal of Consumer Studies, 40(3), 345-356. https://doi.org/10.1111/ ijcs. 12261

28. Heider, R., \& Moeller, S. (2012) Outlet Patronage in On-the-go 
Consumption: An Analysis of Patronage Preference Drivers for Convenience Outlets Versus Traditional Retail Outlets. Journal of Retailing and Consumer Services, 19(3), 313-324. http://dx.doi. org/10.1016/j.jretconser.2012.03.004

29. Hinson, R. E., Anning-Dorson, T., \& Kastner, A. A. N. A. (2012). Consumer Attitude towards Shopping Malls in Sub-Saharan Africa: An Exploration of the "New" Retail Format in Ghana. African Journal of Business and Economic Research, 7(2-3), 97-134. Retrieved from https://journals.co.za/content/ aa_ajber/7/2_3/EJC128581

30. Hoppe, A., Vieira, L. M., \& de Barcellos, M. D. (2013). Consumer Behavior towards Organic Food in Porto Alegre: An Application of the Theory of Planned Behavior. Revista Economia Sociologia Rural, 51(1), 69-90. Retrieved from http://www. scielo.br/scielo.php?script=sci_artte xt\&pid=S0103-20032013000100004

31. Hoyer, W. D., Maclnnis, D. J., \& Pieters, R. (2013). Consumer Behavior (6th ed.). Mason: Southwestern Cengage Learning.

32. Ibok, N. I., \& Umana, V. S. (2013). Behavioral Characteristics and the Marketing Implications of the Low Income Consumers. International Journal of Business Administration, 4(5), 73-78. https://doi.org/10.5430/ ijba.v4n5p73

33. Jen, M. Y., \& Wang, S. M. (2015). Understanding the Purchasing Behavior of Taiwanese Meat Consumers in Light of Rising Sustainability Concerns. British Food Journal, 117(5), 1474-1487. https://doi.org/10.1108/BFJ-062014-0193

34. Joshi, Y., \& Rahman, Z. (2015). Factors Affecting Green Purchase Behavior and Future Research Directions. International Strategic Management Review, 3(1-2), 128143. http://dx.doi.org/10.1016/j. ism.2015.04.001

35. Kakkos, N., Trivellas, P., \& Sdrolias, L. (2015). Identifying Drivers of Purchase Intention for Private Label Brands: Preliminary Evidence from Greek Consumers. Procedia Social and Behavioral Sciences, 175, 522-528. https://doi.org/10.1016/j. sbspro.2015.01.1232
36. Kline, R. B. (2011). Principles and Practice of Structural Equation Modelling (3rd ed.). New York: Guilford Press. Retrieved from https://www.guilford.com/books/ Principles-and-Practice-of-Structural-Equation-Modeling/RexKline/9781462523344

37. Kotler, P., \& Armstrong, G. (2012) Principles of Marketing (14th ed.). New Jersey: Pearson Education.

38. Kotler, P. (1965). Behavioral Models for Analyzing Buyers. Journal of Marketing, 29(4), 37-45. https://doi. org/10.2307/1249700

39. Kumar, A., Dangi, H. K., \& Vohra, A. (2015). The Purchase Pattern of Poor for Fast Moving Consumer Goods: An Empirical Study of Poor in India. International Journal of Management and Business Research, 5(2), 79-94. Retrieved from http:// ijmbr.srbiau.ac.ir/article_6380.html

40. Kurajdova, K., \& TaboreckaPetrovicova, J. (2015). Literature Review on Factors Influencing Milk Purchase Behavior. International Review of Management and Marketing, 5(1), 9-25. Retrieved from https://www.econjournals. com/index.php/irmm/article/ view/1029

41. Kwon, Y. S., \& Song, H. R. (2015). The Role of Opinion Leaders in Influencing Consumer Behaviors with a Focus on Market Mavens: A Meta-analysis. Athens Journal of Mass Media and Communications, 43-54. http://dx.doi.org/10.30958/ ajmmc.1-1-3

42. Lee, V. H., Ooi, K. B., Tan, B. I., \& Chong, Y. L. (2010). A Structural Analysis of the Relationship between TQM Practices and Product Innovation. Asian Journal of Technology Innovation, 18(1), 7396. https://doi.org/10.1080/1976159 7.2010.9668683

43. Leedy, P. D., \& Ormrod, J. E. (2010). Practical Research: Planning and Design (Upper Saddle River). NJ: Merrill Prentice Hall.

44. Leeraphong, A., \& Mardjo, A. (2013). Trust and Risk in Purchase Intention through Online Social Network: A Focus Group Study of Facebook in Thailand. Journal of Economics, Business and Management, 1(4),
314-318. https://doi.org/10.7763/ JOEBM.2013.V1.68

45. Lincoln, Y. S., Lynham, S. A., \& Guba, E. G. (2011). Paradigmatic Controversies, Contradictions and Emerging Confluences. In N. K. Denzin \& Y. S. Lincoln (Eds.), The Sage Handbook of Qualitative Research (4th ed.) (pp. 97-128). Thousand Oaks, CA: Sage.

46. Liu, M. T., Brock, L. J., Cheng, G., Rongwei, S., \& Tseng, C. T. (2013) Perceived Benefits, Perceived Risk and Trust: Influences on Consumers' Group Buying Behavior. Asia Pacific Journal of Marketing and Logistics, 25(2), 225-248. https://doi. org/10.1108/13555851311314031

47. Mehta, R., Sharma, N. K., \& Swami, S. (2013). A Typology of Indian Hypermarket Shoppers Based on Shopping Motivation. International Journal of Retail \& Distribution Management, 42(1), 40-55. https://doi.org/10.1108/ IJRDM-06-2012-0056

48. Miao, M., Jalees, T., Qabool, S., \& Zaman, S. I. (2019). The effects of personality, culture and store stimuli on impulsive buying behavior. Asia Pacific Journal of Marketing and Logistics. https://doi.org/10.1108/ APJML-09-2018-0377

49. Mohan, G., Sivakumaran, B., \& Sharma, P. (2013). Impact of Store Environment on Impulse Buying Behavior. European Journal of Marketing, 47(10), 1711-1732. https:// doi.org/10.1108/EJM-03-2011-0110

50. Mullis, K., \& Kim, M. (2011). Factors Determining in Shopping in Rural US Communities: Consumers' and Retailers' Perceptions. International Journal of Retail and Distribution Management, 39(5), 326-345. https:// doi.org/10.1108/09590551111130757

51. Nguyen, D. H., de Leeuw, S., \& Dullaert, W. E. H. (2016). Consumer Behavior and Order Fulfilment in Online Retailing: A Systematic Review. International Journal of Management Reviews, 1-22. https:// doi.org/10.1111/ijmr.12129

52. Niemelä-Nyrhinen, J., \& Leskinen, E. (2014). Multicollinearity in Marketing Models: Notes on the Application of Ridge Trace Estimation in Structural Equation 
Modelling. The Electronic Journal of Business Research Methods, 12(1), 3-15. Retrieved from https://www.researchgate.net/ publication/287749321_Multicollinearity_in_marketing_models_Notes_on_the_application_of_ ridge_trace_estimation_in_structural_equation_modelling

53. Oke, A. O., Kamolshotiros, P., Popoola, O. Y., Ajagbe, M. A., \& Olujobi, O. J. (2016). Consumer Behavior towards Decision Making and Loyalty to Particular Brands. International Review of Management and Marketing, 6, 43-52.

54. Olsen, S., \& Skallerud, K. (2011). Retail Attributes' Differential Effects on Utilitarian Versus Hedonic Shopping Value. Journal of Consumer Marketing, 28(7), 532-539. https://doi. org/10.1108/07363761111181527

55. Ouma, D., Mwangi, T. D., \& Oduk, P. M. (2013). Modeling Agility in Kenyan Supermarkets Chain Expansion. International Journal of Business and Commerce, 2(8), 21-36.

56. Pandey, S., Khare, A., \& Bhardwaj, P. (2015). Antecedents to Local Store Loyalty: Influence of Culture, Cosmopolitanism and Price. International Journal of Retail \& Distribution Management, 43(1), 5-25, https://doi.org/10.1108/ IJRDM-08-2013-0156

57. Pantano, E. (2011). Cultural Factors Affecting Consumer Behavior: A New Perception Model. EuroMed Journal of Business, 6(1), 117-136. https://doi. org/10.1108/14502191111130343

58. Pietersen, J., \& Maree, K. (2015). First Steps in Research Process. Pretoria: Van Schaik.

59. Priest, J., Carter, S., \& Stat, D. (2013). Consumer Behavior. United Kingdom: Edinburgh Business School Press.

60. Puszczak, K., Fronczyk, A., \& Urbański, M. (2013). Analysis of Sample Size in Consumer Surveys. Taskforce on Quality of BCS Data.

61. Roy, K. (2012). The Co-existence of Kirana Stores and Supermarkets: A Potential Possibility? Journal of Marketing and Communication, 7(3), 64-67.
62. Runyon, K. E., \& Stewart, D. W. (1987). Consumer Behavior and the Practice of Marketing (3rd ed.). Merrill: Columbus, Ohio USA.

63. Salazar, H. A., Oerlemans, L., \& Stroe-Biezen, S. (2013). Social Influence on Sustainable Consumption: Evidence from A Behavioral Experiment. International Journal of Consumer Studies, 37(2), 172-180. https:// doi.org/10.1111/j.14706431.2012.01110.x

64. Sanlier, N., \& Karakus, S. S. (2010). Evaluation of Food Purchasing Behavior of Consumers from Supermarkets. British Food Journal, 112(2), 140-150. https://doi. org/10.1108/00070701011018824

65. Saunders, M., Lewis, P., Thornhill, A., \& Guppa, A. (2007). Research Methods for Business Students. London, UK: Pitman Publishing.

66. Schumacker, R. E., \& Lomax, R. G. (2015). A Beginners Guide to Structural Equation Modelling (4th ed.). New York, NY: Routledge, Taylor \& Francis Group, LLC.

67. Sethi, I., \& Chawla, A. S. (2014). Influence of Cultural, Social and Marketing Factors on the Buying Behavior of Telecom Users: A Comparative Study of Rural, SemiUrban and Urban Areas in and Around Chandigarh. Journal of Marketing Management, 2(1), 97110. Retrieved from http://jmm-net. com/journals/jmm/Vol_2_No_1_ March_2014/7.pdf

68. Shashikiran, L., \& Madhavaiah, C. (2015). Impact of Socio Economic Factors on Purchase Behavior of Organic Food Products. International Journal of Economics and Business Administration, 1(2), 82-86. Retrieved from http://www. aiscience.org/journal/ijeba

69. Tsarenko, Y., Ferraro, C., Sands, S., \& McLeod, C. (2013). Environmentally Conscious Consumption: The Role of Retailers and Peers as External Influences. Journal of Retailing and Consumer Services, 20(3), 302-310. https://doi. org/10.1016/j.jretconser.2013.01.006

70. Vadim, K. D. (n.d.). Income as a Factor of Consumer Behavior of Latvian Inhabitants in Economics and Tourism. Retrieved from https:// www.ukessays.com/.../consumerbehavior-of-low-income-groupsmarketing- (accessed on April 12, 2017).

71. Wang, P., Liu, Q., \& Qi, Y. (2014). Factors Influencing Sustainable Consumption Behaviors: A Survey of the Rural Residents in China. Journal of Cleaner Production, 63, 152-165. https://doi.org/10.1016/j. jclepro.2013.05.007

72. Wingrove, C. A., \& Urban, B. (2017). Franchised Fast Food Brands: An Empirical Study of Factors Influencing Growth. Acta Commercii, 17(1), 431. https://doi. org/10.4102/ac.v17i1.431

73. Wu, P. C. S., Yeh, G. Y. Y., \& Hsiao, C. R. (2011). The Effect of Store Image and Service Quality on Brand Image and Purchase Intention for Private Label Brands. Australasian Marketing Journal, 19(1), 30-39. https://doi.org/10.1016/j.ausmj.2010.11.001

74. Yang, A., Do, B., Wang, G. L., Chang, L. Y., \& Hung, F. C. (2011). Assessing Competitiveness of Foreign And Local Supermarket Chains In Vietnamese Market by Using Fuzzy TOPSIS Method. Journal of Business Management and Economics, 2(5), 209-216. Retrieved from https://ideas.repec.org/a/etr/ series/v2y2011i6p209-216.html

75. Yap, M. C., Tong, D. Y. K., \& Lai, K. P. (2011). Consumers' Perceptions towards International Supermarket Private Brand Products. International Journal of Social Sciences and Humanity Studies, 3(1), 271-280. Retrieved from https://www.researchgate.net/ publication/281774357_consumers'_perceptions_towards_international_supermarket_private_brand_ products

76. Zairis, A. G., \& Evangelos, P. (2014). Consumer Behavior toward Convenience Store Chains in Greece. EuroMed Journal of Business, 9(2), 175-197. https://doi. org/10.1108/EMJB-03-2013-0010 